\title{
Research and Practice on Individualized Training of Teaching Ability for Young Teachers
}

\author{
Yong-Gang YANG \\ Beijing Institute of Graphic Communication, \\ Beijing, China \\ 2207063089@qq.com
}

\author{
Li-Zhen YANG \\ Beijing Institute of Graphic Communication, \\ Beijing, China \\ yanglizhen@bigc.edu.cn
}

\begin{abstract}
The construction of teaching staff is the premise to ensure the quality of education and teaching. Young teachers are the fresh force of teaching and educating people. Strengthening the cultivation of young teachers' teaching ability is the key to improve the level of education and teaching. This paper first analyses the predicament of young teachers' development, and then systematically expounds the path of individualized cultivation of young teachers' teaching ability from three aspects, finally puts forward the planning and development trend of young teachers' team construction from six aspects, which provides a useful reference for the growth of young teachers' teaching ability and practical innovation ability in our school.
\end{abstract}

Keywords-Young teachers; Teaching ability; Individualized training; First-class major; Teaching Team

\section{INTRODUCTION}

First-class undergraduate majors need first-class teachers, and the basic project of teacher team construction is to strengthen the training of young teachers' teaching ability. Young teachers are an important component of the teaching staff of colleges, and are the fundamental factors affecting the quality of higher education in China. The abilities of young teachers are of vital importance to the development of schools. The young teachers introduced by our school are mainly doctoral students. They mainly come from scientific research institutes and 985 or 211-project sponsored colleges. Most of them have received formal and systematic professional education. Their professional knowledge is solid and their research ability is strong. However, due to their non-normal background and lack of opportunities to practice in enterprises, their teaching ability and practical guidance abilities are both slight. It is obviously insufficient, which is inconsistent with the current requirements of Local Applied Undergraduate Colleges for young teachers' engineering practice ability[1]. How to effectively improve young teachers' teaching ability and engineering practice ability is an urgent problem to be solved. Personalized training is one of the effective ways.

\section{The PRESENT Situation AND DilemMa of YounG TEACHERS' DEVELOPMENT}

There is an urgent need to improve the understanding of the new concept of modern teaching. Influenced by traditional teaching concepts and outdated knowledge concepts, some young teachers believe that teaching is the process of knowledge transmission and reproduction, not the process of creating and discovering truth. Subjectively, they do not attach enough importance to teaching, and they do not really regard the concept of capacity-building as their teaching leading ideology.

Teachers' ability to deal with and balance the relationship between teaching and scientific research needs to be improved. In-depth teaching process will inspire scientific research ideas; rigorous scientific research results can feed back teaching and promote teaching. However, due to the problem of scientific research orientation at the social and school levels, young teachers are unable to prepare the teaching content and design the teaching process in a limited amount of energy and time, and there is still room for improvement in teaching and educating people [2].

The support given by the school to team building is not strong, and the integration of young teachers is limited. Schools have always stressed the need to strengthen scientific research and teaching team building, but did not give more freedom and financial support to team building, resulting in insufficient team cohesion, limited integration of young teachers, unable to form a larger team to work together to tackle key projects and declare major achievements.

\section{ThE PATH OF INDIVIDUALIZED TRAINING OF YounG TEACHERS' TEACHING ABILITY}

\section{A. Guiding young teachers to participate in teaching competitions and enterprise exercises to enhance their social practice and innovation ability}

Young teachers in our college participate in the teaching basic skills competition, prepare and polish the teaching demonstration, teaching plan and PT carefully, and effectively improve the teachers' own classroom teaching level and professional accomplishment. Others, such as high-quality classroom awards, the selection of famous young teachers, multimedia courseware or micro-class design competitions, are stages for teachers to experience and display. In addition, teachers instruct students to participate in various professional level of academic competitions (such as printing professional skills competition, digital media design competition, packaging structure innovation design competition, etc.)[3]. The level of students' award-winning level is also an indirect reflection of teachers' professional level to a large extent.

The school encourages newly recruited young teachers to practice in printing, packaging enterprises or ink, consumables 
and adhesives production enterprises for no less than 3 to 6 months without the requirement of teaching workload. Teachers can not only improve their engineering practice ability, but also find the starting point of scientific research in the service industry by taking advantage of this valuable practice opportunity. Teachers participate in the guidance of Beijing's "Practical Training Program" project. Through cooperation with Chinese Academies of Sciences and famous universities, they strengthen communication, broaden their horizons and enhance their practical and innovative abilities. On the platform of printing and packaging comprehensive innovation practice base (municipal level), teachers promote the diversification of practical teaching methods and improve teachers' own practice and innovation ability by offering innovative practice projects, guiding students to participate in subject competitions and leading students to participate in social practice activities.

B. Widening the channels of young teachers' further education and training, and promoting the growth of teachers' professional competence

In order to strengthen discipline and specialty construction and enhance teachers' bilingual teaching ability, school of printing and packaging engineering recommends young doctorates to participate in the post-doctoral workstation project research, and encourages teachers to pursue doctoral degrees on-the-job and various types of academic refresher and training tasks. At present, the newly introduced young doctorates in our institute have basically entered the station in the past five years [4]. They have applied for funding from the National Natural Science Foundation of China (Youth Project) and Beijing Post-doctoral Research Activities- - A project, and have completed or are carrying out post-doctoral research.

Through the training of new teachers' professional competence, the tutorial system for young teachers, and the teaching skills training platform of the Teacher Teaching Development Center, the Printing and Baggage College has rapidly improved teachers' teaching competence. At the same time, young professional teachers are encouraged to carry out academic degree promotion programs, expand visits to universities and enterprises at home and abroad, and cooperate with schools and enterprises. Over the past three years, there have been six on-the-job Ph.D. degrees for professional teachers in school of printing and packaging, and three teachers have completed six months of bilingual teaching competence training in American universities. Fifteen young teachers have studied abroad or visited schools, and more than 20 have gone abroad to attend international academic conferences.

Through further study, visits and academic exchanges outside the country, young teachers have increased their own insights, broadened their international horizons, improved their professional skills and scientific research level, and promoted the overall quality of key teachers in school of printing and packaging [5].

\section{Implementing the tutorial system, the "Three-Three Systems" of Course Teaching and the "Help and Lead" Mechanism of Teaching Team}

Through the young teachers' tutorial system and teaching supervision system, our college gives all-round guidance to newly recruited teachers in teaching theory, methods and skills, and strives to improve classroom teaching ability and level. Young and middle-aged backbone teachers can make full use of advanced teaching means and resources, use modern information means such as micro-class, blue-ink class, rain class in classroom teaching, and combine teaching content to make "flip classroom" attempts, such as "packaging printing technology", "functional materials and devices", "color science and technology" and other courses.

With experienced professors as the core, school of printing and packaging constructs a reasonable teaching team for the old, middle-aged and young people, and carries out the effect of transmission, assistance and cascade within the team, until teaching experience and teaching skills are imparted to young teachers to help them grow up as soon as possible. There are 25 to 28 courses in our college every semester, and about 78 full-time front-line teachers. According to the different curriculum attributes, we can basically construct the "three-three system" of teaching "three teachers can attend a course and one teacher can attend three courses", and the curriculum team implements the "transmission and guidance" mechanism. At the same time, our institute has distinct industry attributes, and has established more than 10 off-campus practical teaching bases and some alliances of industry, University and research cooperation. In the process of teaching, we often employ enterprise tutors from the bases or alliances to participate in classroom teaching, graduation design guidance, teaching seminars and curriculum team building. In addition, the teaching supervisory group of our school has strengthened the monitoring of teaching quality and the guidance of teaching behavior, giving full play to the role of diagnosis and evaluation of specialties, courses and teaching links.

\section{Planning And DeVelopment TREnd of Young TEACHERS' TEAM CONSTRUCTION}

Strengthen the construction of young teachers' morality and style of teaching, encourage them to devote themselves to asking questions in ordinary posts, earnestly follow teaching, be a good teacher of "four possessions", strengthen the cultivation of morality and three qualities, integrate ideological and political education into professional classroom teaching, and be good teachers, mentors and guides for students' growth.

Make full use of the talent training and exchange platform built by the Beijing Education Committee and the school, encourage young teachers to study and train abroad, encourage new teachers to take up their posts in industrial enterprises, improve the international communication ability, engineering practice ability and scientific research and development ability of the teaching staff, so as to enhance the overall quality of the teaching staff.

Teachers are encouraged to declare teaching reform projects, curriculum construction and compilation of characteristic 
textbooks at all levels, support teachers to publish high-level teaching research papers, strive to achieve each teacher's "one-appointment-one-teaching-research project" and "one-year-one-teaching-reform thesis". The College holds a "Young Teachers' Basic Teaching Skills Competition" every two years. The college also cooperates with the Teacher Teaching Development Center and the College of Mechanical and Electrical Engineering to conduct training sessions for young teachers to enhance their teaching skills, so that famous teachers can one-to-one guide young teachers to conduct teaching exercises, teaching plan writing and teaching PPT production [6].

Depending on several Beijing-level intramural teaching, scientific research platforms and off-campus practical teaching bases, such as the comprehensive training center of printing engineering, the comprehensive innovation practice base of printing and packaging, the printing and packaging materials and technology, and the printing and electronic engineering technology center, we will carry out school-enterprise cooperation, integration of production and education, and enhance young teachers' teaching, scientific research and society. Service ability, the formation of school-level teaching team 5, scientific research team 7 .

A series of incentive measures concerning classroom teaching quality, teaching achievements, famous teachers and other aspects have been introduced, and measures for monitoring and implementing the teaching quality of the unit have been formulated. The main measures adopted are student evaluation, teaching supervision, peer listening and evaluation, mid-term teaching inspection and other means to improve the teaching effect of young teachers from multiple dimensions and in the whole process. Assessment and evaluation should be carried out to form a strong supervision and management of teaching operation $[7,8]$.

With the excellent teaching team of Beijing Printing Engineering as the core and the excellent teaching teams of packaging engineering and international education of printing specialty as the wings, the College will constitute the main body of the theoretical teaching team of the unit, and promote the cross-integration of teaching resources and strength with the "three-three-system" of curriculum teaching, so as to enable young teachers to work and grow up in the team building.

\section{CONCLUSION}

Young teachers are the backbone of sustainable development of schools. Their teaching ability and professional practice ability should be improved in an all-round way. This paper focuses on three major aspects to elaborate the path of individualized cultivation of young teachers' teaching ability, and points out the planning and relevant measures for the construction of teachers' team. Through individualized training, the ability and professional level of young teachers will be fully and effectively improved, and the foundation of teachers in our school will be further consolidated.

\section{ACKNOWLEDGMENT}

This work was financed by 2019 key projects of teaching reform research of Beijing Institute of Graphic Communication.

\section{REFERENCES}

[1] K. Wang, Y. Q. Jin. Research on individualized training path of young teachers in local engineering colleges relying on teacher development center[J], Ability and Wisdom, 2017(4):154-156.

[2] Y. L. Wang, L. Tian, X. H. Wu et al. Discussion on the guiding mechanism of young college teachers' teaching ability training[J], Education Modernization, 2019(5):76-77.

[3] Y. B. Yin, J. Zhou, L. C. Li et al. Practice and thoughts on improving the practical ability of young postgraduate tutors with mentoring[J], Contemporary Education Research and Teaching Practice, 2019(4):215-216

[4] L. Jiang. Thoughts on the improvement of young teachers' teaching ability in colleges under the new situation[J], Journal of Taiyuan Urban Vocational College, 2019(5):56-58.

[5] L. A. Zhang, D. W. Dai. Path Choice for Young Teachers in Local Engineering Colleges to Improve Teaching Ability[J], Western China Quality Education, 2019(6): 109-110.

[6] S. L. Zhang. Strategies of training young teachers' teaching ability in colleges from a multidimensional perspective[J], China Adult Education. 2019(3):88-91.

[7] Y. Li , L. L. Xu, A. L. Hou et al. Study on development mode of young teachers under the background of innovation and entrepreneurship in universities[J], Research and Exploration in Laboratory, 2019(6):243-247.

[8] Liu Dachuan, Wang Ying, Wu Chengzhu et. al. The Analysis of the Promotion Effect of Teaching Competition on the Teaching Ability of University Teachers [J], Future and Development, 2019(6):108-112. 